\title{
Polycystic Ovary Syndrome in Overweight and Normal Weight Women: The Relationships with Inflammatory Markers
}

\section{Kilolu ve Normal Kadınlarda Polikistik Over Sendromunun Enflamatuvar Belirteçlerle İlişkisi}

\author{
(D) Tolga Atakul11, (1) Özgür Deniz Turan¹, (1) Çiğgdem Yenisey²
}

${ }_{1}^{1}$ dnnan Menderes University Faculty of Medicine, Department of Obstetrics and Gynecology, Aydın, Turkey

2Adnan Menderes University Faculty of Medicine, Department of Medical Biochemistry, Aydın, Turkey

Abstract

Objective: The etiology and pathophysiology of Polycystic Ovary syndrome (PCOS) are not yet clearly explained as the disease has a heterogeneous clinical presentation. Several cytokines produced by the ovary and other tissues contribute to the maintenance of a chronic inflammatory state and metabolic imbalance in PCOS. The present study aims to widen the scientific scope concerning the association between the inflammatory state and PCOS through the measurement and evaluation of several inflammatory markers.

Method: Forty-nine medication-naive PCOS patients and 39 healthy controls were enrolled in this case-control study. Blood samples were obtained for the measurement of inflammatory markers.

Results: Cyclooxygenase-2 (COX-2), IL-12, IL-18, IL-23, Krüppel-like factor-4 (KLF-4), peroxisome proliferator-activated receptor (PPAR)gamma, sirtuin (SIRT) and toll-like receptor-2 (TLR-2) were found to be significantly higher in the PCOS group compared to the healthy controls. There were no significant differences regarding these inflammatory markers when overweight and normal weight PCOS women were compared $(p>0.05)$. Receiver operating characteristic curve analysis revealed that the following cut-off values had satisfactory sensitivity and specificity for the diagnosis of PCOS: $5.9 \mathrm{ng} / \mathrm{mL}$ for COX-2, $22.3 \mathrm{pg} / \mathrm{mL}$ for IL-12, $32 \mathrm{pg} / \mathrm{mL}$ for IL-18, $57 \mathrm{pg} / \mathrm{mL}$ for IL-23, $203 \mathrm{pg} / \mathrm{mL}$ for KLF4, $2.54 \mathrm{ng} / \mathrm{mL}$ for PPAR-gamma, $2.9 \mathrm{ng} / \mathrm{mL}$ for SIRT, and $2 \mathrm{ng} / \mathrm{mL}$ for TLR-2.

Conclusion: Our findings demonstrate that these inflammatory markers might be used to identify patients with PCOS with high sensitivity and specificity. Our results support the consideration that the low-grade inflammation observed in women with PCOS is likely intrinsic to the pathophysiology of the disease.

Keywords: Cyclooxygenase-2, interleukins, krüppel-like factor-4, lowgrade inflammation, polycystic ovary syndrome

\section{Öz}

Amaç: Polikistik Over sendromunun (PCOS) etiyolojisi ve patofizyolojisi henüz açıklanamamıştır, çünkü hastalık heterojen klinik tabloya sahiptir. Over ve diğer dokular tarafından üretilen birkaç sitokin, PCOS'de kronik bir enflamatuvar durumun ve metabolik dengesizliğin korunmasına katkıda bulunur. Bu çalışma, çeşitli enflamatuvar belirteçlerin ölçümü ve değerlendirilmesi yoluyla enflamatuvar durum ile PCOS arasındaki ilişkiyi ve bilimsel kapsamı genişletmeyi amaçlamaktadır.

Yöntem: Bu olgu-kontrol çalışmasına ilaç kullanmamış 49 PCOS hastası ve 39 sağlıklı kontrol dahil edildi. Enflamatuvar belirteçlerin ölçümü için kan örnekleri alındı. Siklooksijenaz-2 (COX-2), IL-12, IL-18, IL-23, Krüppel benzeri faktör-4, peroxisome proliferator-activated receptor (PPAR)gama, sirtuin (SIRT) ve geçiş ücreti benzeri reseptör-2 (TLR-2) ölçümleri yapıldı.

Bulgular: PCOS grubunda sağlıklı kontrollere göre COX-2, IL-12, IL18, IL-23, Krüppel benzeri faktör-4, PPAR-gama, SIRT ve TLR-2 anlamlı olarak daha yüksek bulundu. Aşırı kilolu ve normal kilolu PKOS kadınları karşılaştııılı̆̆ında bu enflamatuvar belirteçler açısından anlamlı fark yoktu $(p>0,05)$. Alıcı işletim karakteristiği analizi, aşağıdaki kesme değerlerinin PCOS tanısı için tatmin edici duyarlıığa ve özgüllüğe sahip olduğunu ortaya koymuştur: COX-2 için 5,9 ng/mL, IL-12 için 22,3 pg/ $\mathrm{mL}$, IL-18 için $32 \mathrm{pg} / \mathrm{mL}, 57 \mathrm{IL}-23$ için $\mathrm{pg} / \mathrm{mL}$, Krüppel benzeri faktör-4 için $203 \mathrm{pg} / \mathrm{mL}$, PPAR-gama için 2,54 ng/mL, SIRT için 2,9 $\mathrm{ng} / \mathrm{mL}$ ve TLR-2 için $2 \mathrm{ng} / \mathrm{mL}$.

Sonuç: Bulgularımız, bu enflamatuvar belirteçlerin PCOS'li hastaları yüksek duyarlıık ve özgüllükte tanımlamak için kullanılabileceğini göstermektedir. Sonuçlarımız PCOS'li kadınlarda gözlenen düşük dereceli enflamasyonun muhtemelen hastalığın patofizyolojisine özgü olduğu düşüncesini desteklemektedir.

Anahtar kelimeler: Düşük dereceli enflamasyon, interlökinler, krüppel benzeri faktör-4, Polikistik Over sendromu, siklooksijenaz-2

Address for Correspondence: Tolga Atakul, Adnan Menderes University Faculty of Medicine, Department of Obstetrics and Gynecology, Aydın, Turkey E-mail: tolgaatakul@gmail.com ORCID: orcid.org/0000-0002-0219-000X Received: 05.03.2020 Accepted: 14.04.2020

Cite this article as: Atakul T, Turan ÖD, Yenisey Ç. Polycystic Ovary Syndrome in Overweight and Normal Weight Women: The Relationships with Inflammatory Markers. Bagcilar Med Bull 2020;5(2):45-51

${ }^{\odot}$ Copyright 2020 by the Health Sciences University Turkey, Bagcilar Training and Research Hospital Bagcilar Medical Bulletin published by Galenos Publishing House. 


\section{Introduction}

Polycystic Ovary syndrome (PCOS) is the most common and complex endocrine disorder among women of reproductive age with an estimated prevalence ranging between $5 \%$ and $15 \%$ (1). Given the established associations between PCOS and several diseases including cardiovascular diseases, type 2 diabetes, dyslipidemia, obesity and infertility, PCOS represents a major challenge regarding potential long-term morbidity, mortality and increased health-care costs (2).

The etiology and pathophysiology of PCOS are not yet clearly explained as the disease has a heterogeneous clinical presentation. Several genetic and environmental factors as well as lifestyle are believed to have a role in the development and progression of PCOS. Hyperinsulinism due to insulin resistance and hyperandrogenism are considered to be the primary underlying conditions that lead to the development of this syndrome $(3,4)$. Studies have shown that insulin resistance is present in more than half of the patients with PCOS, irrespective of weight and obesity (5). The overstimulation of the insulin receptors of follicular theca cells by the synergistic action of hyperinsulinism and luteinizing hormone (LH) is likely the major cause of the hyperandrogenism and associated ovulatory dysfunction observed in PCOS women (6). Although the mode of inheritance is still unclear, familial clustering of the cases and higher prevalence of the syndrome in identical twins compared to non-identical twins suggest that genetic susceptibility may also contribute to PCOS development (7).

Recently, several pieces of research have been published investigating the relationship between chronic low-grade inflammation and PCOS. Adipokines and inflammation mediators produced by the adipose tissue have been shown to contribute to the metabolic changes presenting in PCOS (8). Moreover, several cytokines produced by the ovary and other tissues are considered to cause a chronic inflammatory state which maintains the metabolic imbalance(s) observed in the syndrome $(9,10)$. However, current data are available for only a minority of inflammatory markers.

The present study aims to widen the scientific scope concerning the association between the inflammatory state and PCOS through the measurement of several previously unassessed inflammatory markers. This study also aims to address the potential role of inflammatory markers in the diagnosis of PCOS.

\section{Materials and Methods}

All consecutive female patients (age, 18 to 40 years) diagnosed with PCOS at the Department of Gynecology, Adnan Menderes University, Aydın, Turkey between June 2015 and July 2016 were enrolled in this cross-sectional study. The diagnosis of PCOS was based on the revised diagnostic criteria by the Rotterdam ESHRE/ASRMSponsored PCOS consensus workshop group (11). A group comprised of healthy volunteers was also included in the study as a control group. Those who had any chronic diseases or infectious diseases within 3 months of enrollment, and pregnant patients or those in the initial six weeks of the post-partum period and breastfeeding women were excluded from the study. Written informed consent was obtained from all participants included in the study. The study was approved by the Institutional Ethical Committee and was performed in accordance with the most recent version of the Helsinki Declaration (2017/1131). Age, body mass index (BMI), menstrual cycle (ir) regularity, presence of hirsutism, and the systolic and the diastolic blood pressures of all patients were recorded.

Blood samples following a 12-hour fasting were drawn from all participants for fasting blood glucose, insulin, follicle stimulating hormone (FSH), LH, thyroid stimulating hormone (TSH), estradiol, prolactin, total testosterone, cyclooxygenase-2 (COX-2), interleukin-12, interleukin-18, interleukin-23 (IL6), Krüppel-like factor-4 (KLF-4), peroxisome proliferator-activated receptor (PPAR)gamma, sirtuin-1 (SIRT1) and toll-like receptor-2 (TLR-2) measurements. After centrifugation $(4000 \times \mathrm{g}$ for $10 \mathrm{~min})$, 1 to $2 \mathrm{~mL}$ serum samples for the measurement of the aforementioned inflammatory markers were stored at -80 ${ }^{\circ} \mathrm{C}$ until being assayed. Enzyme-linked immunosorbent assay was performed to determine the serum levels of these inflammatory markers. Insulin resistance was determined by using the homeostasis model assessment HOMA-IR formula as follows:

(HOMA-IR) formula [HOMA-IR = fasting insulin $(\mathrm{mIU} / \mathrm{mL})$ $\times$ fasting glucose $(\mathrm{mg} / \mathrm{dL}) / 18) / 22.5$ ]

The predictive value of the inflammatory markers for identifying PCOS was the primary outcome of the present study.

\section{Statistical Analysis}

All analyses were performed on SPSS v21 (IBM, Armonk, USA). For the normality check, the KolmogorovSmirnov test was used. Normally distributed variables (height, weight, and blood glucose) were compared with 
the independent samples t-test, while non-normally distributed variables were compared with the MannWhitney U test. Chi-square test or Fisher's exact test were used to compare the categorical variables. Data were given as mean \pm standard deviation or median (minimum - maximum) for continuous variables with regard to normality, and as frequency (percentage) for categorical variables. Diagnostic performance of each variable was assessed by performing receiver operating characteristic (ROC) curve analysis. A p-value $<0.05$ was accepted to show statistical significance.

\section{Results}

A total of 49 medication-naive PCOS patients [median age 21 (18-39)] and 39 healthy controls [median age 22 (1940)] were enrolled in this cross-sectional study. Patients' average weight was higher in the PCOS group compared to the healthy controls $(68.76 \pm 13.90 \mathrm{~kg}$ vs. $61.38 \pm 8.89 \mathrm{~kg}$, $\mathrm{p}=0.005)$. However, the number of overweight and obese patients were similar in the two groups. Patients with POCS and controls were similar with regard to systolic and the diastolic blood pressures. Menstrual cycle irregularity and hirsutism were more frequent in PCOS patients compared to controls. FSH, prolactin and TSH levels were similar among groups, while total testosterone, fasting blood glucose and insulin levels, and the HOMA index were higher in PCOS patients. LH and the estradiol levels were also higher in the PCOS group compared to the control group (Table 1).

Inflammatory markers including COX-2, IL-12, IL-18, IL23, KLF-4, PPAR-gamma, sirtuin (SIRT), and TLR-2 were significantly higher in PCOS patients than the controls. ROC curve analysis revealed that the following cut-off values provided satisfactory sensitivity and specificity for the diagnosis of PCOS:5.9 ng/mL for COX-2, $22.3 \mathrm{pg} / \mathrm{mL}$ for IL-12, $32 \mathrm{pg} / \mathrm{mL}$ for IL-18, $57 \mathrm{pg} / \mathrm{mL}$ for IL-23, $203 \mathrm{pg} /$ $\mathrm{mL}$ for KLF-4, $2.54 \mathrm{ng} / \mathrm{mL}$ for PPAR-gamma, $2.9 \mathrm{ng} / \mathrm{mL}$ for SIRT, and $2 \mathrm{ng} / \mathrm{mL}$ for TLR-2 (Table 2, Figure 1).

\section{Discussion}

The present study demonstrates that COX-2, IL-12, IL18, IL-23, KLF-4, PPAR-gamma, SIRT, and TLR-2 are significantly higher in patients with PCOS compared to healthy controls. The blood levels of inflammatory markers were similar in overweight PCOS women and normal weight PCOS women. Our findings also demonstrate that these inflammatory markers might be useful in identifying patients with PCOS with high sensitivity and specificity.
PCOS is a common and complex endocrinopathy which effects $5 \%$ to $15 \%$ of reproductive-age women. Recent data indicate that adiposity and low-grade inflammatory state are two main factors contributing to the development of PCOS (12). Due to the fact that adipose tissue acts as an endocrine organ by releasing adipokines, cytokines, and several hormones, the increased levels of inflammatory markers in PCOS women were initially suggested to be due to PCOS-related adipocyte hypertrophy. In support of this hypothesis, it is known that adipocytes are vulnerable to hypertrophy when exposed to excessive androgen stimulation, as is the case in women with PCOS. Hyperandrogenism and the hypertrophy of adipocytes lead to stromal vessel compression which further induces adipose tissue hypoperfusion (13). Activation of nuclear factor kappa-B, which is a transcription factor mediating inflammatory processes, by adipose tissue hypoperfusion stimulates the release of various inflammatory cytokines, including interleukins $(1 \beta, 6,10$, and 18$)$, tumor necrosis factor alfa (TNF- $\alpha$ ), interferon gamma, complement factors, transforming growth factor $\beta$, monocyte chemotactic protein-1 (MCP-1) and vascular cell adhesion molecule (8). The resultant macrophage recruitment maintains inflammatory state and leads to adipocyte dysfunction. PCOS ovarian tissue has been shown to contain more macrophages and lymphocytes than the ovarian tissues of controls in previous studies (14). Increased blood concentrations of TNF- $\alpha$, interleukins (IL-6, IL-18, IL-1 $\beta$, IL-7, IL-17), MCP-1, macrophage inflammatory protein$1 \alpha$, macrophage migration inhibitory factor, matrix metalloproteinases (MMP) 2 and 9, soluble intercellular adhesion molecule-1 and soluble endothelial leukocyte adhesion molecule-1 have been shown in PCOS (15).

It has also been postulated that low-grade inflammation itself might be a precursor for the development of insulin resistance and the characteristic ovarian dysfunction in patients with PCOS. Nevertheless, whether low-grade inflammation and the altered release of adipokines are intrinsic to PCOS or a consequence of PCOS-related adipocyte hypertrophy and hyperandrogenism, is a matter of debate (16). Previous data demonstrated that white blood cell count and the platelet-to-lymphocyte ratio, a marker of proinflammatory state, were significantly higher in obese PCOS patients compared to normal weight PCOS patients. However, neutrophil-to-lymphocyte ratio and mean platelet volume did not differ in obese and normal-weight PCOS patients, although both were found to be higher than in the healthy controls $(17,18)$. Prior studies have demonstrated significantly higher levels of high-sensitive C-reactive 
protein, IL-6, and TNF- $\alpha$ in women with PCOS compared to BMI-matched controls (19). Additionally, these markers are also reported to be increased in lean PCOS women suggesting a special association between inflammatory state and PCOS, regardless of obesity-associated alterations (20). The cytokine elevation in PCOS was initially considered as a consequence of the excessive visceral fat deposition, which is known to be related to increased adipocytokine levels in obese patients $(21,22)$. However, several subsequent studies have failed to demonstrate any significant differences in visceral, abdominal subcutaneous, gluteal subcutaneous, or midfemoral subcutaneous fat (as measured by MRI) of women with or without PCOS (21). We found that COX-2, IL-12, IL-18, IL-23, KLF-4, PPAR-gamma, SIRT and TLR-2 were significantly higher in the PCOS group compared to the healthy controls. However, there were no significant

Table 1. Summary of patients' characteristics regarding groups

\begin{tabular}{|c|c|c|c|c|}
\hline & Controls & Pcos & Total & $\mathbf{p}$ \\
\hline $\mathrm{n}$ & 39 & 49 & 88 & N.A \\
\hline Age & $21(18-39)$ & $22(19-40)$ & $22(18-40)$ & 0.227 \\
\hline Height (cm) & $164.41 \pm 6.39$ & $163.51 \pm 5.95$ & $163.91 \pm 6.13$ & 0.497 \\
\hline Weight (kg) & $61.38 \pm 8.89$ & $68.76 \pm 13.90$ & $65.49 \pm 12.44$ & 0.005 \\
\hline Overweight (BMI>25) & $15(38.46 \%)$ & 29 (59.18\%) & $44(50.00 \%)$ & 0.086 \\
\hline Obesity (BMI>30) & $2(5.13 \%)$ & $8(16.33 \%)$ & $10(11.36 \%)$ & 0.175 \\
\hline Systolic BP & $110(90-125)$ & $110(90-152)$ & $110(90-152)$ & 0.385 \\
\hline Diastolic BP & $70(55-80)$ & $70(50-90)$ & $70(50-90)$ & 0.443 \\
\hline \multicolumn{5}{|l|}{ Menstrual Cycle } \\
\hline Irregular & $3(7.69 \%)$ & $35(71.43 \%)$ & 38 (43.18\%) & \multirow{2}{*}{$<0.001$} \\
\hline Regular & $36(92.31 \%)$ & $14(28.57 \%)$ & $50(56.82 \%)$ & \\
\hline \multicolumn{5}{|l|}{ Hirsutism } \\
\hline Absent & $25(64.10 \%)$ & $3(6.12 \%)$ & $28(31.82 \%)$ & \multirow{4}{*}{$<0.001$} \\
\hline Mild & $14(35.90 \%)$ & $15(30.61 \%)$ & 29 (32.95\%) & \\
\hline Medium & $0(0.00 \%)$ & $16(32.65 \%)$ & $16(18.18 \%)$ & \\
\hline Severe & $0(0.00 \%)$ & $15(30.61 \%)$ & 15 (17.05\%) & \\
\hline $\mathrm{FSH}(\mathrm{mlU} / \mathrm{mL})$ & $4.5(2.82-9.00)$ & $4.47(1.33-10.60)$ & $4.50(1.33-10.60)$ & 0.589 \\
\hline $\mathrm{LH}(\mathrm{mlU} / \mathrm{mL})$ & $3.18(0.70-13.46)$ & $4.13(0.71-16.40)$ & $3.61(0.70-16.4)$ & 0.030 \\
\hline Estradiol (pg/mL) & $29(15-82)$ & $40(2-133)$ & $35(2-133)$ & 0.004 \\
\hline Prolactin $(\mathrm{ng} / \mathrm{mL})$ & $13.08(1.62-28.00)$ & $14.95(6.01-52.00)$ & $14.24(1.62-52.00)$ & 0.058 \\
\hline $\mathrm{TSH}(\mathrm{mlU} / \mathrm{mL})$ & $1.38(0.54-2.81)$ & $1.78(0.58-4.69)$ & $1.75(0.54-4.69)$ & 0.280 \\
\hline Total testesterone (ng/dL) & $1.04(0.71-2.10)$ & $1.33(0.56-3.50)$ & $1.17(0.56-3.50)$ & 0.016 \\
\hline Blood glucose (mg/dL) & $83.12 \pm 9.30$ & $89.31 \pm 8.64$ & $87.19 \pm 9.29$ & 0.006 \\
\hline Insulin $(\mu \mathrm{IU} / \mathrm{mL})$ & $6.20(1.42-21.50)$ & $9.35(3.70-31.20)$ & $8.60(1.42-31.20)$ & 0.007 \\
\hline HOMA-IR & $1.39(0.27-4.28)$ & $2.11(0.72-7.16)$ & $1.94(0.27-7.16)$ & 0.003 \\
\hline $\operatorname{coX}-2(\mathrm{ng} / \mathrm{mL})$ & $2.21(0.30-5.96)$ & $6.58(3.66-10.80)$ & $5.53(0.30-10.80)$ & $<0.001$ \\
\hline $\mathrm{IL}-12(\mathrm{pg} / \mathrm{mL})$ & $11.29(6.29-22.18)$ & $32.76(15.41-133.65)$ & $21.44(6.29-133.65)$ & $<0.001$ \\
\hline $\mathrm{IL}-18(\mathrm{pg} / \mathrm{mL})$ & $19.00(9.94-58.06)$ & $48.62(31.75-199.88)$ & $37.06(9.94-199.88)$ & $<0.001$ \\
\hline $\mathrm{IL}-23(\mathrm{pg} / \mathrm{mL})$ & $47.33(15.67-98.17)$ & $92.33(53.17-385.67)$ & $64.83(15.7-385.7)$ & $<0.001$ \\
\hline $\mathrm{KLF}-4(\mathrm{pg} / \mathrm{mL})$ & $170.85(147.8-299.8)$ & $204.26(147.7-884.3)$ & $196.20(147.7-884.3)$ & $<0.001$ \\
\hline PPAR-gamma (ng/mL) & $1.15(0.24-3.44)$ & $4.58(1.37-9.70)$ & $2.67(0.24-9.7)$ & $<0.001$ \\
\hline $\operatorname{SIRT}(\mathrm{ng} / \mathrm{mL})$ & $1.37(1.29-3.22)$ & $3.42(3.20-6.97)$ & $3.25(1.29-6.97)$ & $<0.001$ \\
\hline TLR-2 (ng/mL) & $1.29(0.38-2.70)$ & $3.62(1.11-9.64)$ & $2.23(0.38-9.64)$ & $<0.001$ \\
\hline
\end{tabular}

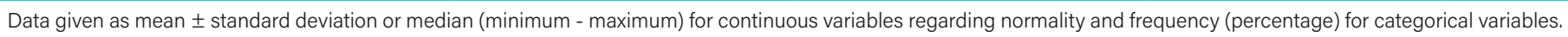

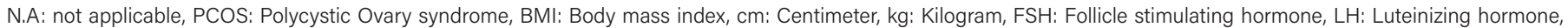

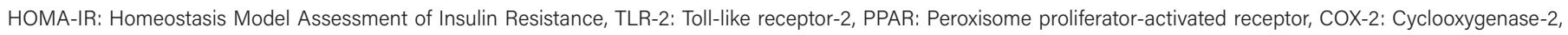
TSH: Thyroid stimulating hormone, BP: Blood pressure, SIRT: Sirtuin, KLF-4: Krüppel-like factor-4 
differences regarding these inflammatory markers when overweight and normal-weight PCOS women were compared. This indicates an intrinsic pathology of PCOS regarding pro-inflammatory state.

In the current study, we assessed the levels of several inflammatory markers which were not studied previously in PCOS, including COX-2, IL-12, IL-18, IL-23, KLF-4, PPAR-gamma, SIRT and TLR-2, which were found to be significantly higher in patients compared to the controls. These markers are utilized in the evaluation of the different pathways of inflammation and higher concentrations show the presence of a global activation of inflammation in PCOS women. Furthermore, the high sensitivity and specificity for the diagnosis of PCOS with these markers support the

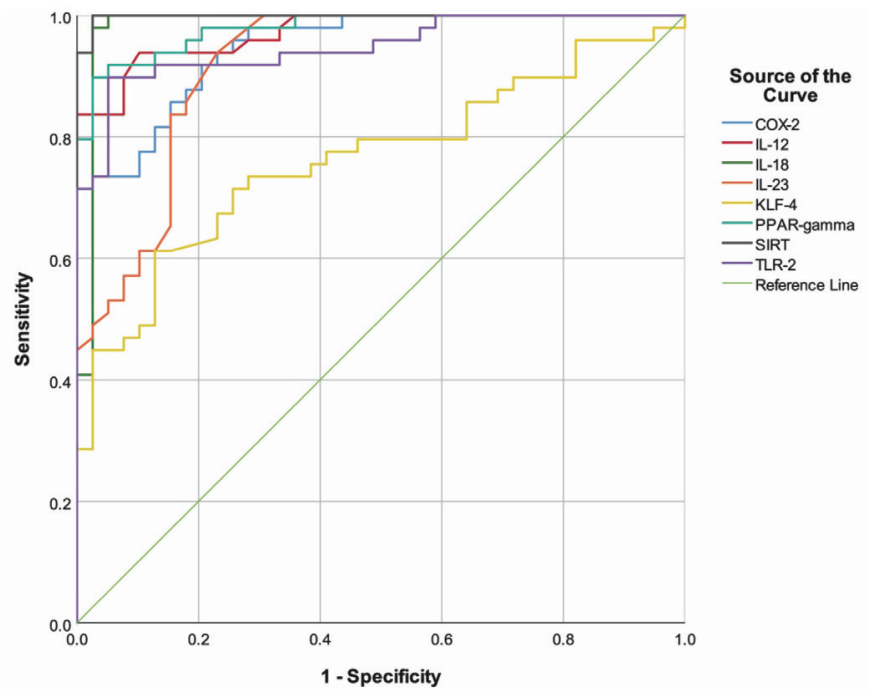

Figure 1. ROC curve demonstrating the diagnostic performance of the inflammatory markers in identifying women with PCOS

PCOS: Polycystic ovary syndrome, COX-2: Cyclooxygenase-2, PPAR: Peroxisome proliferator-activated receptor, TLR-2: Toll-like receptor-2, SIRT: Sirtuin, ROC: Receiver operating characteristic evidence derived from previous studies which suggest a significant role for low-grade inflammatory activity in the development of PCOS. When we elucidate the diagnostic predictivity of the parameters we measured in our study, significant results were found in ROC analysis. It was observed that all of the other markers except the KLF-4 results showed high $(>0.90)$ Area under receiver operating characteristic curve values in predicting PCOS diagnosis. These remarkable results demonstrate that these markers can be used in a diagnostic sense; however, it is obvious that more extensive studies are needed. It is also important to note that there are several other studies that have been performed for the evaluation of these markers, but it is evident that the findings of our research are important.

There is also evidence that the inflammatory state can itself promote androgen production and hyperandrogenemia. An experimental study conducted by Spaczynski and colleagues has shown that TNF- $\alpha$ can stimulate proliferation of ovarian theca cells in murine models (23). In addition, a systematic review including 31 studies, carried out by Escobar-Morreale et al. (24) has revealed that PCOS women exhibit an elevated circulating C-reactive protein, which is independent of obesity. The reduction in serum concentrations of the inflammatory markers with atorvastatin and simvastatin, which have been shown to exert remarkable antiinflammatory effects, also supports the specific role of inflammation in PCOS $(25,26)$. With these results in mind, we suggest that our findings support the consideration that low-grade inflammation and the altered release of the adipokines are intrinsic to PCOS pathophysiology. However, although only a few, there are also some studies indicating increased visceral fat accumulation in normal-weight PCOS women $(27,28)$. Therefore, one could consider that a patient with PCOS does not

\begin{tabular}{|c|c|c|c|c|c|c|c|c|c|c|}
\hline \multirow[b]{2}{*}{ COX-2 (ng/mL) } & \multirow{2}{*}{$\begin{array}{l}\text { Cut-off } \\
5.9\end{array}$} & \multirow{2}{*}{$\begin{array}{l}\text { Sensitivity } \\
71.40 \%\end{array}$} & \multirow{2}{*}{$\begin{array}{l}\text { Specificity } \\
100.00 \%\end{array}$} & \multirow{2}{*}{$\begin{array}{l}\text { Accuracy } \\
84.09 \%\end{array}$} & \multirow{2}{*}{$\begin{array}{l}\text { PPV } \\
100.00 \%\end{array}$} & \multirow{2}{*}{$\begin{array}{l}\text { NPV } \\
73.58 \%\end{array}$} & \multirow{2}{*}{$\begin{array}{l}\text { AUC } \\
0.947\end{array}$} & \multicolumn{2}{|c|}{$95.0 \% \mathrm{Cl}$} & \multirow{2}{*}{$\begin{array}{l}\mathbf{p} \\
<0.001\end{array}$} \\
\hline & & & & & & & & 0.907 & 0.987 & \\
\hline IL-12 (pg/mL) & 22.3 & $71.40 \%$ & $100.00 \%$ & $84.09 \%$ & $100.00 \%$ & $73.58 \%$ & 0.972 & 0.945 & 0.999 & $<0.001$ \\
\hline IL-18 (pg/mL) & 32 & $98.00 \%$ & $97.40 \%$ & $97.73 \%$ & $97.96 \%$ & $97.44 \%$ & 0.984 & 0.954 & 1,000 & $<0.001$ \\
\hline IL-23 (pg/mL) & 57 & $93.90 \%$ & $76.90 \%$ & $86.36 \%$ & $83.64 \%$ & $90.91 \%$ & 0.919 & 0.862 & 0.977 & $<0.001$ \\
\hline $\mathrm{KLF}-4(\mathrm{pg} / \mathrm{mL})$ & 201 & $61.20 \%$ & $87.20 \%$ & $72.73 \%$ & $85.71 \%$ & $64.15 \%$ & 0.763 & 0.664 & 0.863 & $<0.001$ \\
\hline PPAR-gamma (ng/mL) & 2.54 & $89.80 \%$ & $97.40 \%$ & $93.18 \%$ & $97.78 \%$ & $88.37 \%$ & 0.979 & 0.956 & 1.000 & $<0.001$ \\
\hline $\operatorname{SIRT}(n g / m L)$ & 2.9 & $100.00 \%$ & $97.40 \%$ & $98.86 \%$ & $98.00 \%$ & $100.00 \%$ & 0.998 & 0.995 & 1.000 & $<0.001$ \\
\hline TLR-2 (ng/mL) & 2 & $89.80 \%$ & $94.90 \%$ & $92.05 \%$ & $95.65 \%$ & $88.10 \%$ & 0.948 & 0.904 & 0.992 & $<0.001$ \\
\hline
\end{tabular}

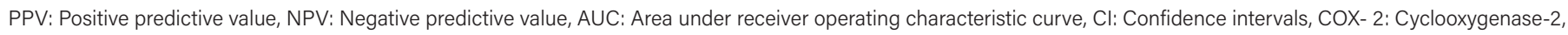
PPAR: Peroxisome proliferato-activated receptor, TLR-2: Toll-like receptor, SIRT: Sirtuin 
necessarily need to have a high BMI for the development of adipocyte-associated inflammatory activation. This particular finding can be considered as a limitation of the current study, as we did not assess visceral fat deposition. Further research, including the measurement of the visceral fat accumulation, will probably serve additional information concerning the clarification of the role of inflammation and obesity in the pathogenesis of PCOS.

We have to underline the fact that a few previous reports have shown higher accumulation of fat in the viscera of normal-weight PCOS patients. This accumulation may cause insulin resistance, adipocyte dysfunction and lowgrade inflammation, even though patients have normal BMI. Although our findings indicate that the low-grade inflammatory state observed in PCOS is irrespective of BMI value, we have not measured the visceral fat accumulation. However, there are also studies that report a lack of difference in visceral fat deposition between patients with PCOS and healthy individuals. The relatively low number of patients included in this study is also another drawback.

\section{Conclusion}

The present study shows that inflammatory markers, including COX-2, IL-12, IL-18, IL-23, KLF-4, PPAR-gamma, SIRT and TLR-2, are increased in PCOS regardless of BMI. Our findings also demonstrate that these inflammatory markers might be used to identify patients with PCOS, with high sensitivity and specificity. The lack of any difference in the serum concentrations of the aforementioned inflammatory markers in overweight and normal-weight PCOS patients supports the consideration that the lowgrade inflammation shown in women with this syndrome is intrinsic to PCOS.

\section{Ethics}

Ethics Committee Approval: The study was approved by the Institutional Ethical Committee and was performed in accordance with the most recent version of the Helsinki Declaration (2017/1131).

Informed Consent: Written informed consent was obtained from all participants included in the study.

Peer-review: Externally peer-reviewed.

\section{Authorship Contributions}

Consept: T.A., Ö.D.T., Ç.Y., Design: T.A., Data Collection or Processing: T.A., Ç.Y., Analysis or Interpretation: T.A., Ö.D.T., Literature Search: T.A., Ö.D.T., Ç.Y., Writing: T.A., Ö.D.T., Ç.Y.
Conflict of Interest: No conflict of interest was declared by the authors.

Financial Disclosure: The authors declared that this study received no financial support.

\section{References}

1. Bozdag G, Mumusoglu S, Zengin D, Karabulut E, Yildiz BO. The prevalence and phenotypic features of polycystic ovary syndrome: a systematic review and meta-analysis. Human reproduction 2016;31(12):2841-2855.

2. Goldrat O, Delbaere A. PCOS: update and diagnostic approach. Clinical biochemistry 2018;62:24-31.

3. Meier RK. Polycystic Ovary Syndrome. The Nursing clinics of North America 2018;53(3):407-420.

4. Nandi A, Chen Z, Patel R, Poretsky L. Polycystic ovary syndrome. Endocrinology and metabolism clinics of North America 2014;43(1):123-147.

5. Moghetti P. Insulin Resistance and Polycystic Ovary Syndrome. Current pharmaceutical design 2016;22(36):5526-5534.

6. Rosenfield RL, Ehrmann DA. The pathogenesis of polycystic ovary syndrome (PCOS): the hypothesis of PCOS as functional ovarian hyperandrogenism revisited. Endocrine reviews 2016;37(5):467520.

7. Vink J, Sadrzadeh S, Lambalk C, Boomsma D. Heritability of polycystic ovary syndrome in a Dutch twin-family study. The Journal of Clinical Endocrinology \& Metabolism 2006;91(6):21002104.

8. Spritzer PM, Lecke SB, Satler F, Morsch DM. Adipose tissue dysfunction, adipokines, and low-grade chronic inflammation in polycystic ovary syndrome. Reproduction 2015;149(5):R219-R227.

9. ÇakıroğluY,VuralF, Vural B. The inflammatory markers in polycystic ovary syndrome: association with obesity and IVF outcomes. Journal of endocrinological investigation 2016;39(8):899-907.

10. Durmus U, Duran C, Ecirli S. Visceral adiposity index levels in overweight and/or obese, and non-obese patients with polycystic ovary syndrome and its relationship with metabolic and inflammatory parameters. Journal of endocrinological investigation 2017;40(5):487-497.

11. The Rotterdam ESHRE/ASRM-Sponsored PCOS Consensus Workshop Group. Revised 2003 consensus on diagnostic criteria and long-term health risks related to polycystic ovary syndrome. Fertility and sterility 2004;81(1):19-25.

12. Ebejer K, Calleja-Agius J. The role of cytokines in polycystic ovarian syndrome. Gynecological endocrinology 2013;29(6):536-540.

13. Spritzer PM, Lecke SB, Satler F, Morsch DM. Adipose tissue dysfunction, adipokines, and low-grade chronic inflammation in polycystic ovary syndrome. Reproduction 2015;149(5):R219-227.

14. Xiong YL, Liang XY, Yang X, Li Y, Wei LN. Low-grade chronic inflammation in the peripheral blood and ovaries of women with polycystic ovarian syndrome. European Journal of Obstetrics \& Gynecology and Reproductive Biology 2011;159(1):148-150.

15. Deligeoroglou E, Vrachnis N, Athanasopoulos N, Iliodromiti Z, Sifakis S, Iliodromiti S, et al. Mediators of chronic inflammation in polycystic ovarian syndrome. Gynecological Endocrinology 2012;28(12):974-978. 
16. Shorakae S, Teede H, de Courten B, Lambert G, Boyle J, Moran LJ. The Emerging Role of Chronic Low-Grade Inflammation in the Pathophysiology of Polycystic Ovary Syndrome. Seminars in reproductive medicine 2015;33(4):257-269.

17. Dogan BA, Arduc A, Tuna MM, Karakilic E, Dagdelen I, Tutuncu Y, et al. Association of mean platelet volume with androgens and insulin resistance in nonobese patients with polycystic ovary syndrome. International journal of endocrinology and metabolism 2014;12(4):e18642.

18. Cakiroglu Y, Vural F, Vural B. The inflammatory markers in polycystic ovary syndrome: association with obesity and IVF outcomes. J Endocrinol Invest 2016;39(8):899-907.

19. Ebejer K, Calleja-Agius J. The role of cytokines in polycystic ovarian syndrome. Gynecological Endocrinology 2013;29(6):536-540.

20. Samy N, Hashim M, Sayed M, Said M. Clinical significance of inflammatory markers in polycystic ovary syndrome: their relationship to insulin resistance and body mass index. Disease markers 2009;26(4):163-170.

21. Barber T, Franks S. Adipocyte biology in polycystic ovary syndrome. Molecular and cellular endocrinology 2013;373(1-2):68-76.

22. Zhuang XF, Zhao MM, Weng CL, Sun NL. Adipocytokines: a bridge connecting obesity and insulin resistance. Medical hypotheses 2009;73(6):981-985.
23. Spaczynski RZ, Arici A, Duleba AJ. Tumor necrosis factorstimulates proliferation of rat ovarian theca-interstitial cells. Biology of Reproduction 1999;61(4):993-998.

24. Escobar-Morreale HF, Luque-Ramirez M, Gonzalez F. Circulating inflammatory markers in polycystic ovary syndrome: a systematic review and metaanalysis. Fertil Steril 2011;95(3):1048-1058.

25. Sathyapalan T, Kilpatrick ES, Coady A-M, Atkin SL. The effect of atorvastatin in patients with polycystic ovary syndrome: a randomized double-blind placebo-controlled study. The Journal of Clinical Endocrinology \& Metabolism 2009;94(1):103-108.

26. Banaszewska B, Pawelczyk L, Spaczynski RZ, Duleba AJ. Comparison of simvastatin and metformin in treatment of polycystic ovary syndrome: prospective randomized trial. The Journal of Clinical Endocrinology \& Metabolism 2009;94(12):49384945 .

27. Sathyapalan T, Atkin SL. Mediators of inflammation in polycystic ovary syndrome in relation to adiposity. Mediators of inflammation 2010;2010:758656.

28. Kirchengast S, Huber J. Body composition characteristics and body fat distribution in lean women with polycystic ovary syndrome. Human Reproduction 2001;16(6):1255-1260. 